\title{
SHELLEY AND DEBUSSY *
}

Sigrid Renaux

The aim of this article (which claims neither to exhaust the subject nor to prove that Debussy's music was actually inspired by Shelley's poems) is to show the great affinity there was between both artists, as to subject matter and inspiration, bringing to our minds again the fact that all art is interrelated and how one mans' genius throws light on another's. This unfailing interest and excitement found in the arts, of an artist trying honestly to express the spirit of his age, is the reward we have in letting our sensibility open to their appeal.

As has been said by Irwin Edman in hist book Arts and the Man,'

"It is the peculiar power of certain works of art (not always the most ambitious or grandiloquent to touch off in us, to suggest in themselves, a reality that transcends the diurnal world of common sense and of common logic'... "This transcended reality may be hinted at by a mere modulation as in some of the slow movements of Mozart's sonatas; it may be brilliant yellow in a Van Gogh, or a sudden line or two of Shakespeare:

"For God's sake let us sit upon the ground And tell sad stories of the death of kings'.

Every art critic is aware of the common phenomenon of unconscious similarity between two artists, who, in different

- Trabalho elaborado em 1971.

(1) Irwin Edmon, Arts and the Man (Now York: Mentor Books, 195I) p. 135.6. 
times and countries have had the same themes or subjects of inspiration. If we compare the themes of Debussy's and of Shelley's artistic output, we are struck by the correspondences we find in their sensitivity to the beauty of nature surrounding them: the sea, the wind, the sky, clouds floating by, boats and sails, a storm, autumn leaves, sounds and perfumes. This similarity of themes is the more striking if we remember that both belonged to almost opposite movements: Shelley was the epitome of the Romantic Movement in England, the supreme individualist, who protested against all kinds of tyranny and who lived his short life to the full. Overwhelmed by the forces of nature he loved so much, he was drowned while sailing off the bay of Lerici, in Italy.

Shelley brought to Romantic poetry an almost unearthly beauty. He was by nature a rebel against convention and all that seemed to him to hinder the full expression of a free spirit. His themes are a kaleidoscope of romantic themes, and show the universality of his mind - a Renaissance mind plus revolt and uncertainty of the Romantics. We are hypnotized by his poetry even when it does not make sense. As F.R. Leavis says in his Revaluation, ${ }^{2}$ Shelley represents most nearly in the Romantic Period the complete rejection of the past, and he at the same time represents pre-eminently the divorce between thought and feeling, intelligence and sensibility, that is characteristic of the nineteenth century.

The fact that Shelley seems unreadable nowadays is partly due to the impressions made on him by nature. Leavis confirms, in "Poetry for Poetry's Sake" this impression of suggestion found in Shelley's poetry:

"About the best poetry and not only the best, there floats an atmosphere of infinite suggestion. The poet speaks to us of one thing, but in this one thing there seems to lurk the secret of all; he said what he meant, but his meaning seems to beckon away beyond itself, to expand into something boundless which is only focussed in it; something which would satisfy not only the imagination, but the whole of us; that something within us, and without, which everywhere

“... make us seem

To patch up fragments of a dream

(2) F.R. Leavis, Revaluation (Londen: Chatto and Windus, 1962) P. 203.

(3) A.C. Bradley, Oxford Lectures on Poetry (Lendon: Macmillan \& Co.Lida., 1934) p. 26. 
Part of which comes true, and part Beats and trembles in the heart". (Shelley)

Debussy, on the other hand, is the founder of the Impressionist School in music, the "father of atonalism" in twentieth century music, who revolted against the classical tradition and against the decadence of Romantic music. With Debussy, France finds its own musical values again, taking the supremacy that Wagner had been holding for a century. Debussy's musical themes evoke the sensation conveyed by nature in a play of light, colour and shade, capturing the sensitive and fugitive impressions man has of the world around him, by his free use of harmonies and rhythms and unusual tonal colours. Human sentiments are no longer explored, there is neither confession, nor pure reality.

Debussy's profession of faith is a proof of the inexhaustibility of the spectacles of nature as a source of inspiration:

"Je crois que la musique" a reposé jusq'ici sur un principe faux. On cherche des idées en soi alors qu'on devrait les chercher autour de soi. On combine, on construit, on imagine des thèmes qui veulent exprimer des idées, on les développe ou on les modifie à la recontre d'autres thèmes qui représentent d'autres idées. On fait de la métaphysique, on ne fait pas de la musique. On n'écoute pas assez autour de soi les mille bruits de la nature, on ne guette pas assez cette musique si variée qu'elle nous offre avec tant d'abondance. Elle nous enveloppe et nous avons vécu au milieu d'elle sans nous en apercevoir".

We end with his famous words: "Voir lever le soleil est plus utile pour un compositeur que d'entendre la Symphonie Pastorale de Beethoven".

Using the whole-tone scale, without semitones, Debussy succeeded in softening the expression of the emotion that inspired the composition, as well as veiling the clear statement of formal construction. His harmonies, derived from "overtones", create the mood or atmosphere. As to the case of Shelley's poems, his music was at once felt to be very individual. He was more preoccupied with "tone qua tone", colour being more important than form, mood more than narrative, like the impressionist painters who said that "light is the

(4) Claudo Debussy, Exlampes, Images, (a Pathe Martoni record, played by Walter Gieseking, commentary by Em!lo Vuillerngl. 
chief personage in a picture" (Monet). Debussy avoided the "dramatic, the narrative, the formal, the conventional and the involved" in music. But his "school" is also related to the Symbolist poets of France, like Baudelaire, Mallarmé, Verlaine and others, who tried to express in their poems a "delicate sensitive voluptuousness, suggesting their meaning rather than stating it"'.

From Leavis's comment on Shelley's power of evocation, we see that Shelley in a way anticipated the Symbolist movement in poetry. We reach back and see how an English poet, born seventy years before Debussy, provided him whith themes for inspiration: one could speak of an involuntary aproximation between Debussy and Shelley, were it not for the fact that Debussy actually read Shelley's poems. It is absurd to imagine that Debussy, a young and poor artist, who bought Shelley's whole collection of works richly leather-bound and translated into French, was not in some manner influenced by him. (It had to be sold later, when Debussy was in need, but some time afterwards he bought it back again).

Both were rebels, in their own way. Both shared a passion for the Italian landscape, for Shelley spent the last five years of his life in Italy, and Debussy lived there for some time as the winner of the Grand Prix de Rome. Shelley was sent down from Oxford, Debussy failed in Harmony at the Music Conservatory in Paris. Neither really became very famous in their lifetime, like Byron or Wagner (their contemporaries), and their artistic output was many times rejected by their editors. Shelley's pantheism, the almost disembodied beauty of his lyrics are also observable in Debussy's music. Yet examining Debussy's work at closer range, one sees that it possesses balance and restraint, and also definite melodic themes artistically handled. There is a strong programmatic element in Debussy, treated with aristocratic refinement, just as Shelley's "profuse strains of unpremeditated art"" also rest on a classical structure, even if he tried to free poetry from its classical forms.

Now if we compare some of Shelley's nature descriptions with Debussy's we will find not only this astonishing similarity of mood and of feeling, but the art of describing in music

(5) Percy A. Scholes, Oxford Companion to Music (Oxford University Press, 1970) p. 282.

(6) Ibid.

(7) Percy B. Shelley, "To a Skylark", Solections from Shelley's Poetry and Prase ed. Dennis Welland London: Hutchinsen Educatienal Ltd., 1961) p. 105. 
and in words "the indescribable". For the sake of clarity we could classify the pieces that are going to be compared under these headings: influences of the elements (water, air, fire, earth), Italian and Oriental influences, legendary and supernatural influences. (These influences are sometimes intermingled, of course).

\section{1 - Water}

Doubtlessly, Shelley's and Debussy's loftiest common theme is the sea. Both artists have a fluid quality, for there is hardly a piece or theme that does not evoke in somme way the sea, rain, or water drops. The attraction Debussy felt for the sea as a boy found its mode of expression in his manhood: $L a$ Mer, Sirènes, La Cathédrale Engloutie, Reflets dans l'Eau, Jardins sous la pluie and others, are compositions in which one visualizes the vastness of the sea in all its might, with its old legends of mermaids and sunken cities, or the sound produced by a single drop of rain falling on the surface of a pond. This fascination for the sea is also felt by Shelley: one of his recurring symbols is the boat, for Shelley as a boy was fond of sailing paper boats for amusement and as a grown man, images of fragile boats veer and glide down the magical stream of his poetry.

"La Mer"s - The same mysterious inner nature of the sea is perceived by Shelley and Debussy. If we hear Debussy's orchestral masterpiece, "La Mer", with its three movements

1 - Del l'Aube à Midi sur la Mer

2 - Jeux des Vagues

3 - Dialogue du Vent et de la Mer

in which the composer gives us not only a vivid and sonorous picture of winds and waves, of surge and ebb, of the shining sun and dancing spray seen on the sea's surface, but also of the mysteries suggested by dark and deep waters, which the sun rays reach only at noon, Shelley's words come to mind: we hear

“... the Earth and Ocean when they seem

To sleep in one another's arms, and dream

Of waves, flowers, clouds, woods, rocks, and all that we Read in their smiles, and call reality".

(Epipsychidion) $^{9}$

(B) Claude Debussy, La Mer (RCA record, with Arturo Toscanini and NBC Symphonic Orchestral.

(9) Shelley, "Epipsychidion", cp. cit., p. 135. 
The same joy felt in listening to waves playing in Jeux des Vagues and to the wind blowing is transmited to us Shelley's "Julian and Maddalo") (actually Shelley and Byron), when both ride near Venice on a summer evening: ${ }^{10}$

"This ride was my delight. I love all waste And solitary places; where we taste The pleasure of believing what we see Is boundess, as we wish our souls to be: And such was this wide ocean, and this shore More barren than its billows; and yet more Than all, with a remembered friend I love To ride as then I rode; - for the winds drove The living spray along the sunny air Into our faces; the blue heavens were bare, Stripped to their depths by the awakening north; And, from the waves, sound like delight broke forth Harmonizing with solitude, and sent Into our hearts aëreal merriment".

In "La Mer" we hear "the fearful war of wave ruining on wave"," we see "the sun lingering o'er his ocean floor", 12 until "some respite to its turbulence unresting ocean knows", is "for the weary winds are silent, or the moon is in the "deep" " But in the third movement, the sea is awakened by the wind announcing the approaching storm:

"Afar the melancholy thunder moaned,

Pale Ocean in unquiet slumber lay,

And the wild winds flew round, sobbing in their dismay" [(Adonais) ${ }^{15}$

The wind, the "trumpet of a prophecy"' is heard in the trumpet blown probably by a sea god, and one senses the approach of some gigantic force, for whose path

“... the Atlantic's level powers

Cleave themselves into chasms, while far below

The sea-blooms and the cozy woods which wear

Thy voice, and suddenly grow gray with fear

And tremble and despoil themselves..." (Ode to the [West Wind) ${ }^{17}$

(10) Ibid., "Julion and Madda:o", p. 48.

(11) ib.d., "Alastor", p.28.

(12) ibid., "The Triumph of Life", p. 177

(13) Percy B. Shelley, "Stanzas"' April, 814. Poutical Works, ed. Thomas Hutchinson (Oxford

(14) ibid.

(15) ibid., "Adonais", Solectiens... p.151.

(16) ibid." "Ode to the West Wind", p.99.

(i7) ibid., pp.99.100. 
Shelley and Debussy seemed to have that intuitive perception of the mysterious nature of the sea, of the truths which Oceanography had not yet discovered. Shelley's note about this stanza reads: "This phenomenon... is well known to naturalists. The vegetation at the bottom of the sea, of rivers and of lakes, sympathizes with that of the land in the change of seasons, and is consequently influenced by the winds which announce it". 18

In Debussy's piece, one senses the immortality of the sea, its antiquity, its force, its life, and we can say with Shelley:

"Unfathomable Sea! whose waves are years,

Ocean of Time, whose waters of deep woe

Are brackish with the salt of human tears!

Thou shoreless flood, which in thy ebb and flow

Claspest the limits of mortality,

And sick of prey, yet howling on for more,

Vomitest thy wrecks on its inhospitable shore;

Treacherous in calm, and terrible in storm,

who shall put forth on thee,

Unfathomable Sea? (Time) ${ }^{19}$

We turn now to a series of piano pieces related to water. That sense of the right note, the illuminating dissonance the telling overtones that haunted Debussy from the beginning till the end of his career is in no place more acutely felt than in these piano pieces, in which he could exploit no new nuances of wood wind-brass combinations, no unusual percussion nor "eletronic" importations.

"La Cathédrale Engloutie"2o: the shore-dwellers of Brittany (France) have a legend that, in the calm of a moonlitnight, the ancient cathedral of Ys may rise from the waves that sweep over it, its bells ringing, its priests chanting long-forgotten prayers. All this Debussy has set before us in magical detail through the use of modal tonalities, great clanging chords to depict the bells, and a splash of Gregorian colour for the ritual. The evocation is amazing and its resolution breathtaking.

(18) ibid., p.259.

(19) ibid., "Time", Poetical Works, p. 637.

(20) Debussy, "La Cathédrale Engloutie", Est:mpes, Próludas, Bo:k 1 (Westminster record, played by Reine Gianoli. 
Shelley describes another sea, it is noon, but the mood and the intangible underwater beauty are the same:

"Thou who didst waken from his summer dreams

The blue Mediterranean, where he lay,

Lulled by the coil of his crystalline streams,

Beside a pumice isle in Baiae's bay,

And saw in sleep old palaces and towers

Quivering within the wave's intenser day,

All overgrown with azure moss and flowers

So sweet, the sense faints picturing them!"... (Ode to the West Wind) ${ }^{21}$

It is the same quivering that pervades the submerged cathedral of Ys, when its bells resound and it rises from the waves, that wakens the old palaces and towers of Baiae, "within the wave's intenser day". Shelley had visited Baiae by boat from Naples in 1818 and describes it in a letter to Peacock, praising the grandeur "of its submarine ruins standing like rocks in the transparent sea under our boat". These were the ruins of Roman villas, one of which had been owned by Julius Caesar. ${ }^{22}$

In "Reflets dans l'Eeau" we have the reflections and deep whirlpools, a miracle of sonorous transposition of "jeux de lumière", of the elasticity and transparency of a water surface. Shelley, describing a rivulet in "Alastor", also conveys to us this magic sound of water drops falling on a liquid surface:

"Sometimes it fell

Among the moss with hollow harmony

Dark and profound. Now on the polished stones

It danced: like childhood laughing as it went;

Then, through the plain in tranquil wanderings crept,

Reflecting every herb and drooping bud

That overhung its quietness".,24 of the

But we also have in "Reflets dans l'Eau" a darker image,

"... wild woods and the plains,

And the pools where winter rains

Image all their roof of leaves"...

(21) Shelley, "Ode to the West Wind", Selostions... p. $\varphi 9$.

(22) ibid., p. 258.

(23) Debussy, "Reflets dans l'Eau". Evrampes, Images (Pathé Mareoni record).

(24) Shelley, "Alastor", op. cir., p.33. 
Debussy's isolated drops at the end of his piece linger to fall and to dissolve into tones, "like dew upon a sleeping flower", like a "tear some dream has loosened from his brain"2:

"Jardins sous la pluie"27 - A sudden summer rain in Orbec (Ile de France) inspired Debussy to compose this "estampe", in which he liberates the charm of the soul of things; print finds its poetic counterpart in Shelley's "The Cloud", bringing "fresh showers for the thirsting flowers" some lines from the poem "To a Skylark", with its

"Sound of vernal showers

On the twinkling grass,

Rain-awakened flowers,

All that ever was

Joyous, and clear, and fresh"...29

"L'Isle Joyeuse"30 - composed during Debussy's flight to the Isle of Jersey with Emma, his future wife, conveys to us all the happiness of those fleeting moments surrounded by green meadows and sandy shores. (It was originally named 'L'Embarquement pour Cythère - after Watteau). L'Isle Joyeuse brings back to us Shelley's enchanted island, his realm of ideal poetry, where he has taken Emilia Viviani, his "spirit's sister":

"It is an isle under jonian skies,

Beautiful as a wrack of Paradise...

And all the winds wandering along the shore

Undulate with the undulating tide:

There are thick woods where sylvan forms abide;

And many a fountain, rivulet, and pond,

As clear as elemental diamond,

Or serene morning air;...

And all the place is peopled with sweet airs;

The light clear element which the isle wears

Which floats like mist laden with unseen showers,

And falls upon the eyelids like faint sleep...

It is an isle twixt Heaven, Air, Earth, and Sea,

Cradled, and hung in clear tranquillity;

Bright as that wandering Eden Lucifer,

Washed by the soft blue Oceans of young air". ${ }^{31}$

(25) ibid., "To Jane: The Invitation", Poefical Works, p. 669.

(26) ibid., "Ad-nais", Selections; p.íl49.

(27) Debussy," "Jordins sous la pluie", op.cit.

(2B) Shelley, "The Cloud", op.cit., p.io2.

(29) ibld., "To a Skylark", op.cit., p.107.

(30)) Debusssy, "L’lsle Joyeuse"," Oeuvses pour Piano (Paris: Durand \& Cie.)

(31) Sheliey, "Epipsychidion", op. cit., p. 133. 
"Voiles"32 - As Oscar Thompson notes in his work "Debussy, Man and Artist" 33 "Voiles" can be translated either as veils or sails. The French do not doubt that he had sails in mind, a concept attested by the nature of this water colour: it ebbs and flows through figures based on the whole-tone scale, which float above, truly sail-like. Sails are also a recurrent theme in Shelley:

"I sat and saw the vessels glide

Over the ocean bright and wide,

Like spirit-winged chariots sent

O'er some serenest element...

And the wind that winged their flight

From the land came fresh and light,

And the scent of wingèd flowers,

And the coolness of the hours

Of dew, and sweet warmth left by day

Were scattered o'er the twinkling bay"... ${ }^{34}$

Now if we take a look at Monet's painting "Sails at Argenteuil" we have a complete poetic, melodic and pictorial image of sails, all in one.

"En Bateau"3s - is another invitation to sail, taken from Debussy's Petite Suite; an invitation repeated by Shelley to Emilia Viviani:

"A ship is floating in the harbour now,

A wind is hovering o'er the mountain's brow;

There is a path on the sea's azure floor,

No keel has ever ploughed before;

The halcyons brood around the foamless isles;

The treacherous Ocean has forsworn its wiles;

The merry mariners are bold and free:

Say, my heart's sister, wilt thou sail with me?

Our bark is as an albatross, whose nest

is a far Eden of the purple East;

And we between her wings will sit, while Night,

And Day, and Storm, and Calm, pursue their flight'... ${ }^{36}$

"Ondine" - the charms of the water sprite, and the treacherous depths she inhabits were musicalized with such grace and seductiveness as the nocture "Sirènes", 38 in which

(32) Debussy, "Voiles", op.cis.

(33) ibid.

(34) Shel'oy, "Lines Written in the Bay of Lerici", Poetical Works, p.674.

(35) Debussy, "En Bateau", Petite Suife, op.cit.

(36) Shelley, "Epipsychidion", Selectiens.... pp.132.3.

(37) Debussy, "Ond"ne", Estampes, Pr-ludes, Book II.

(38) ibid., "Sirènes"." Trois Noctures (an Angel record, Msrcel Briclot Choir), Orchestre Nationsle de la Radiodiffusion Françaisc). 
a choir specifies the mythological significance, giving a mysterious and lovely voice to the waves that dance sweetly under the light of the moon. This Nocturne is a perfect example of Debussy's aesthetic ideal, that we should look for ideas outside ourselves, for we live surrounded by nature without being aware of her. His music gives us not material reality, but what is around it, its radiance, its fluidity and its reflections. We know that while the mermaids sang,

"The whispering waves were half asleep,

and The clouds were gone to play"... ${ }^{39}$

and our spirit "like a charmed bark doth swim

Upon the liquid waves "of that" sweet

Far far away into the regions dim

[singing,

Of rapture"... ${ }^{40}$

\section{$I I$ - Air, Wind, Clouds and Sounds}

The wind is another common theme of inspiration for Shelley and Debussy. If we take Shelley's famous "Ode to the West Wind" (in which there is all the urgency of his passion for freedom) and listen to Debussy's prelude " $\mathrm{Ce} q u$ 'a vu le vent d'Ouest", the correspondences are evident. Debussy's prelude pays a tribute to the fury of a Western blast. The build-up of effect is intensified by the clash of rhythms in bass, alto and treble which coalesce in a sweeping arpeggio marked "furieux et rapide":

" $O$ Wild West Wind, thou breath of Autumn's being,

Thou, from whose unseen presence the leaves dead

Are driven, like ghosts from an enchanter fleeing,

Yellow, and black, and pale, and hectic red,

Pestilence-stricken multitudes: $O$ thou,

Who chariotest to their dark wintry bed

The wingèd seeds, where they lie cold and low,

Each like a corpse within its grave, until

Thine azure sister of the Spring shall blow

Her clarion o'er the dreaming earth, and fill

(Driving sweet buds like flocks to feed in air)

With living hues and odours plain and hill:

Wild Spirit, which art moving everywhere;

Destroyer and preserver; hear, oh, hear!"...43

(39) Shelley, "To Jane - The Recollection", "Pootical Works, p.669.

(40) ibid., "Frogment: To one singing', p.541., op.cit.

(41) ibid., "Ode to the West W:nd". Selections op. 98-101.

(42) Debussy, "Cc qu'a vu le vent d'Quest", Estampes. Próludes, Book I

(43) Shelley, p.98. op.cit. 
But the wild west wind is also a dirge, announcing the death of nature:

"Rough wind, that moanest loud

Grief too sad for song;

Wild wind, when sullen cloud

Knells all the night long;

Sad storm, whose tears are vain,

Bare woods, whose branches strain,

Deep caves and dreary main,

Wail, for the world's wrong!"44

In "Le vent dans la plaine", ${ }^{45}$ however, "the blue heavens bend with lightest winds" 46 and one hears "the summer winds that creep from flower to flower" with "an inconstant wing" 47 as light as the pianissimo that pervades the whole prelude. Hearing this prelude, one also thinks of Shelley's

"When soft winds and sunny skies

With the green earth harmonize,

And the young and dewy dawn,

Bold as an unhunted fawn,

Up the windless heaven is gone,

Laugh - for ambushed in the day,

Clouds and whirlwinds watch their prey".48

"Nuages"4 - is another Nocturne that evokes the slow drifting by of clouds against a motionless sky, its almost imperceptible transformations and the melancholy derived from their inexorable wandering into limbo:

"We are as clouds that veil the midnight moon;

How restlessly they speed, and gleam, and quiver,

Streaking the darkness radiantly yet soon

Night closes round and they are lost for ever". so

Shelley's poem "The Cloud"si gives us, as does Debussy's orchestral piece, a changing, rhythmic panorama of the varying moods of cloud life - the tender calm, the laughing thunder, the weeping storm. The cloud is going places and doing things, and has not time to stop to classify the expe-

(44) ibid., "A Dirge", Pootical Works, p.673.

(45) Debussy, "Le Vent dans la Plaine", op.cit.

(46) Shelley, "Epipsychidion", Selections... p. 136.

(47) ibid., "Hymn to Intellectual Beauiy", p.41.

(48) ibid., "Fragment: When seft winds and sunny skies", Poetical Works, p.660.

(49) Debussy, "Nuages", Trois Noctures, op.cit.

(50) Shelley, "Mutability", Selections... p.40.

((51) ibid., "The C'oud", p.102.

(52) ibid., "letter to Maria Gisborne", p.116. 
riences it meets. It swings gaily along from plain to mountain top, shouting and silent by turns, through hail, rain, snow; into the sunrise, on to the sunset, and then garlands the moon with a "girdle of pearls". The cloud's laughter is an expression of joy in realizing the essential immortality of its life, though it may change in form. " The Cloud" has not been transcribed because of its length).

These are only a few instances of cloud descriptions, which are innumerable in Shelley: Clouds that

"sail o er the inverse deep"

Piloted by the many-wendering blast",52 clouds "charioted by the wind", 53 and others are found all over his poetry.

"Les sons et les parfums tournent dans l'air du soir": ${ }^{54}$ the verse is Baudelaire's, the music is Debussy's: in the first touch of evening, the sounds and scents of day mingle in the quiet and cool of dusk, with the effect of intoxication on the "swooning heart" described by Baudelaire. In Debussy's language this is evoked by a constantly more chromatic texture heavier, more languid. But if we take a look at Shelley we find the germ of Baudelaire's symbolism in him; let us see what Shelley says, in "Alastor": he floats to

"The sweep of odorous winds

Upon resplendent clouds"... ${ }^{55}$

Later he describes a dark glen that

"Sends from its woods of musk-rose, twined jasmine,

A soul-dissolving odour, to invite

To some more lovely mystery"..56

One hears in this prelude, "solemn midnight's tingling silentness ${ }^{57}$ for

"Music, when soft voices die,

Vibrates in the memory -

Odours, when sweet violets sicken,

Live within the sense they quicken"... ${ }^{\text {se }}$

Shelley's lyric "To - " in a way anticipates Baudelaire's "Les Fleurs du Mal":

... "Rose leaves, when the rose is dead,

(53) ibid., "Epipsychidi=n", p.129.

(54) Debussy, "Les sons ef les parfums tournent dans l'air du soir", Estampes. Próludes, Bcok I op. cit.

(55) Shelley, "Alastor", p.28.

(56) ibid., p.32.

(57) ib.d., p.19.

(58) ibid.," "To -" (Music, when soft voices die...), p. 138. 
Are heaped for the belovèd's bed;

And so thy thoughts, when thou art gone

Love itself shall slumber on". ${ }^{\circ}$

"Brouillards": $: 0$ the likeness to blended color producing an over-all haze cannot be ignored, as the "damped "chords contribute to the suggestion of wetness; or, in Shelley's words, "like pageantry of fist on an autumnal stream"," we "watch the dim shades as like ghosts they go and come,

and complicate strange webs of melancholy mirth"s2

"Brouillards" also conveys to us all the charm of the morn, "when the golden mists are born". ${ }^{3}$

\section{III - Fire and Light}

"Feux d'Artifice"'64 is a show of musical sparks, tonal rockets and Catherine wheels in sound, with a hint of the "Marseillaise" near the end. They illuminate night like a star that,

... "has fallen upon the earth

Mid the benighted nations,

A quenchless atom of immortal light,

A living spark of Night,

A cresset shaken from the constellation..." $\$ 5$

"Fêtes"'s - This Nocturne gathers the echo of distant. lights and sounds of joy, which are crossed by a procession. an imaginary feast approaching, illuminated and then going away. It is almost a Bacchanalian feast, in which

"Maidens and youths fling their wild arms in air

As their feet twinkle; they recede, and now

Bending within each other's atmosphere,

Kindle invisibly - and as they glow,

Like moths by light attracted and repelled,

Aft to their bright destruction come and go,

Till like two clouds into one vale impelled,

That shake the mountains when their lightnings mingle And die in rain - the fiery band which held

Their natures, snaps - while the shock still may tingle;

(59) ibid.

(60) Debussy, "B:ouillards", Estampes. Próledes, Bock II, op. sir.

(61) Shelley, "Adenais", op.cit., p.150.

(62) ibid., "Stanzas 1814". Poetical Works, p.521.

(63) ibid., "Song" (Rarely c-mmest thou), p. 251.

(64) Debussy, "Feux d'Artifice", Estampes. Préludes, Brok 11, cp. eit.

(65) Shelley, "Fragments written for Hel'as", Poetical Works, p. 648.

(66) Debussy, "Fètes", Trois Nocturnes, op. cis. 
One falls and then another in the path Senseless $-\ldots{ }^{67}$

$$
\text { IV - Earth, Nature }
$$

"Des Pas sur la Neige"'6B - is one of the most poetic piano preludes, with its atmosphere of chill and bleakness by the brief triplet figure heard in the first measure, and repeated twenty-two times. Almost every time it is heard in some slight alteration of interval or supporting harmony. One of Debussy's evaluators has likened it to a footstep which slips and slithers on the uncertain surface. One imagines

"The plains that silent lie

Underneath, the leaves unsodden

Where the infant Frost has trodden

With his morning-wingèd feet,

Whose bright print is gleaming yet;"

But we know that Debussy was inspired by the painting of his time too, for Debussy did for music what his friends, the impressionistic painters did for painting: he penetrated into new territory. An artist should not declare his theme, but only suggest it. If we take a look at Sisley's painting "Snow at Louvenciennes" (Louvre Museum), one has a graphic grasp of "Des pas sur la neige", if this is still necessary. Pissaro, Monet, Jongkind also provide us with graphic clues as to Debussy's "modern" music.

"Feuilles mortes" - is a melancholy prelude, but it could picture a deserted house, with shutters flapping idly in the wind, as well as the dead leaves of the title:

"... and here

The children of the autumnal whirlwind bore

In wanton sport, these bright leaves, whose decay,

Red; yellow, or ethereally pale,

Rivals the pride of summer"71

Back to the "West Wind" we find

..." the leaves dead

Are driven, like ghosts from an enchanter fleeing, Yellow, and black, and pale, and hectic red... ${ }^{72}$

(67) Shelley. "The Triumph of Life", Selections... p. 170.

(68) Debussy, "Des pas sur la neige", Estampas. Próludese, Book II, op. cit.

(69) Shelley, "Lines written among the Euganean Hills", Op. cit., p. 75.

(70) Debussy, "Feuilles Morles", Estimpes. Próludos, Bock II, op. cit.

(7) Shelley, "A!astor", op. cir., p. 36.

(72) ibid., "Ode to the "est Wind", p. 98. 
"Bruyères" - is far less melancholic than the two preludes above: the calmness of this heather landscape is felt in Shelley's "Adonais", when he refers to earth life, in stanza XVIII:

"The airs and streams renew their joyous tone;

The ants, the bees, the swallows reappear;

Fresh leaves and flowers deck the dead Season bier;

The amorous birds now pair in every brake,

And build their mossy homes in field and brere." 14

It is almost an invitation of the poet to his beloved:

"we two will rise, and sit, and walk together,

Under the roof of blue lonian weather,

And wander in the meadows, or ascend

The mossy mountains, where the blue heavens bend

With lightest winds, to touch their paramour"; ... ${ }^{55}$

"La Terrasse des Audiences du Clair de Lune"." - a phrase of Pierre Loti's "L'Inde sans les Anglais" stirred a response in Debussy, and is rendered as "the terrace of the moonlight audiences". There is as much in the Debussyan night as one chooses to find there. This vision of a lanscape with sacred ruins illuminated by the moonlight makes us turn to the vision Alastor had:

\section{"when the moon}

Filled the mysterious halls with floating shades

Suspended he that task, but ever gazed and gazed,

Till meaning on his vacant mind

Flashed like strong inspiration, and he saw

The thrilling secrets of the birth of time"."7

"Clair de Lune"" - is a part of the Suite Bergamasque. The word Bergamasque refers to the region of Bergamo in the north of Italy, where the peasant dancing tune called Bergamasca was originated in the sixteenth and seventeenth centuries. Debussy's first impulse for the Suite was probably Verlaine's "Clair de Lune":

"Votre âme est un paysage choisi

Que vont charmant masques et bergamasques

(73) Debussy, "Bruydres", Estampes. Proludes, Bock II.

(74) Shelley, "Adonsis", op. cit., p. 152.

(75) ib:d., "Epipsychidinon", op. cit., p. 136.

(76) Debussy, "Lo Terrasse des Audiences du Clair de Lune", Estampes. Próludos Book II, op. cit.

(77) Shelley, "Alastor", op. cil. p. 22.

(78) Debussy, "Clair de Lune", Suite Bargamasque (an Angel Record, played by Walter Gieseking). 
Jouant du luth et dansant et quasi

Tristes sous leurs déguisements fantasques" $" 9$ strings

Indeed, they played "a fragile lute on whose harmonious

the breath of heaven did wander"...80

And listening to Debussy's Suite Bergamasque, we say with Shelley, again: "Music, when soft voices die, vibrates in the memory..." Bu But it is the "Clair de Lune", with its evocative notes born from a mood, that made Debussy famous all over the world:

"I. . . bid you look upon the night.

As water does a sponge, so the moonlight

Fills the void, hollow, universal air -

What see you? - unpavilioned Heaven is fair,

Whether the moon, into her chamber gone,

Leaves midnight to the golden stars, or wan

Climbs with diminished beams the azure step"...82

\section{Italian and Oriental Influences}

The attraction of Italy, where Shelley and Debussy lived, is also seen in their work:

"Les collines d'Anacapri": ${ }^{83}$ across the water from Naples lies Capri, and the higher hills of Anacapri. The tarantella which Debussy uses to suggest the locale is more delicate than most heard in those surroundings. Cortos commentary includes a reference to a flute sounding in the background. In Shelley,

"The sun is warm, the sky is clear

The waves are dancing fast and bright,

Blue isles and snowy mountains wear

The purple noon's transparent might,

The breath of the moist earth is light,

sround its unexpanded buds;

Like many a voice of one delight,

The winds, the birds, the ocean floods,

The City's voice itself, is soft like Solitude's"o،

(79) ibid., commentary by Emile Vuillermoz.

(80) She'ley, "Alaster", op. cit., p. 38.

(BI) see above.

(B2) Shelley, "Lelfer to Maria Gisborne", op. cil., p. 116.

(83) Debussy, "Les Collines d'Anacapri", Estampes. Pr-ludes ,Book I, op. cit.

(B4) Sholley, "Stanzas written in Deloction, near Naples", op. cit., p. 77. 
The attraction that travel in the Orient exercised over the Romantic imagination ("to seek strange truths in un discovered lands") is also found in the range of Shelley's geographical references, as in Debussy's "Soirée dans Grenade", "La puerta del vino", "Iberia" (Spanish influences) and others. Let us have a look at the prelude "Canope":

Canope ${ }^{85}$ was a city of ancient Egypt, and the urns that originated there were used for burial purposes in conjunction with mummies. The passion of lamentation is not in this piece; rather the ritual of remembrance for something long gone... Hearing Canope, we also hope "that death did hide from human sight

Sweet secrets, or beside its breathless sleep

That loveliest dreams perpetual watch did keep"

(substitute "did" for "does") so

"But ye yet stand

In a lone land,

Like tombs to mark the memory

Of hopes and fears, which fade and flee

In the light of life's dim morning". ${ }^{87}$

\section{Supernatural and Legendary Influences:}

"Les Fées sont d'exquises danseuses" - in this prelude the moon provides illumination for the fairy dancing, to a band of bluebells, reed pipes, and, perhaps, an Aeolian harp or two:

"As one enamoured is upborne in dream

O'er lily-paven lakes, mid silver mist,

To wondrous music, so this shape might seem

Partly to tread the waves with feet which kissed

The dancing foam: partly to glide along

The air which roughened the moist amethyst..."

(If we change "her" to "them" - the fairies - we can follow Shelley's words listening to Debussy's prelude).

"Prelude à l'Après-midi d'un faune" - Mallarmé said that to name an object is to sacrifice three-quarters of that enjoyment of the poem which comes from the guessing bit

(85) Debussy, "Canope", Estampes. Préludes, book II, op. cit.

(B6) Shelley. "A summer evening churchyard", Poctical Works, p. 525.

(87) ibid., "Lines, 1817", p. 546.

(88) Debussy. "Lés Fées sont d'exquises danseuses", Estampes, Práludes, Book II.

(89) Shelley. "The Triumph cf Life". Selections... p. 178.

(90) Debussy, Prólude : I'Aprts-midi d'un faune (an Angel record, Orchestre Nafienale de lo Radiadifusion Frangaise, flute solo by Fernand Dufrène). 
by bit. As Debussy was a constant guest at Mallarmé's it is not surprising to find him reexpressing in orchestral tone Mallarmé's poem "L'après-midi d'un faune", with all its obscurity, vagueness and loveliness. Besides Mallarmé's ecloque, Debussy was also inspired by François Boucher's paintings. The music suggests a young faun asleep in the murmuring heat of a forest clearing, dreaming of nymphs. Or, as the paintings show, a faun playing the flute while he observes the flight of nymphs in undulating rhythms.

Maurice Ravel used to say that, the only piece he would like to hear in his death hour, to say good-bye to music, was this one. The faun's dream only ends when

"buds and flowers

Warn the obscure inevitable hours,

Sweet meeting by sad parting to renew; - (but there is a hope of continuity at the end, for "Tomorrow to fresh woods and pastures new".

\section{(Letter to Maria Gisborne) ${ }^{91}$}

Horace's "Carpe Diem" comes to our mind, while we imagine the faun playing his flute to the dancing nymphs, and the senses vibrate caressed by the wind, by the light and by the perfumes of this bright forest clearing. Shelley gives us the same counsel as Horace:

"Whilst skies are blue and bright,

Whilst flowers are gay,

Whilst eyes that change ere night

Make glad the day;

Whilst yet the calm hours creep

Dream thou - and from thy sleep

Then wake to weep".92

- This tone-poem was chosen to end this article, because it is one of the best examples of the principle that all arts are sensuous in their basis and then reach out even to the most abstract of effects. Poetry leads towards an art of sound and towards an art of communication. On the other hand, sound as languege becomes an art in poetry" says Bradley ${ }^{93}$. Sounds speaking poetically is music, one could add. And the

(9i) Shelley, "Lefter to Maris Gisborne". op. cit., p. 118.

(92) ibid., "Mutability, 1B24", Poelical Works, p. 64t.

(93) A. C. Bradley, op. cir., p. 174. 
truths Shelley and Debussy have expressed in words and sounds are more enduring than the physical reality that surrounded them and which surrounds us.

\section{BIBLIOGRAPHICAL REFERENCES:}

1 - Alcock, Richard A. World Literafur* Made Simple. New York: Made Simple Books, 1957.

2 - Arnold, Mathew. Essays in Criticism. London: Everyman's Library, 1969.

3 - Bradley, A. C. Oxford Lectures on Pootry. London; Mocmillan \& Co, Lid., 1934.

4 - Buxton, John. Byron and Shelley, The History of a Friendship. London: Macmillan, 1968 .

5 - Dowden, Edward. The Lifo of Percy Bysshe Shelley. London: Routledge \& Kegan Paul ltd., 1969.

6 - Edman, Irwin. Arts and the Man (a short introduction to aestheties). New York: Mentor Books, 1951.

7 - La Mure, Pierre. Claire de Lune, Biografia Romaneeada de Claude Debussy, tra. dução de Guinara Lobato de Morais Percira. São Paulo: Melhoramentos, 1966.

8 - Leavis, F. R. Revaluation. London: Chatto and Windus, 1962.

9 - Maurois, André. Ariol ou la Vie de Shelley. Paris: Bernard Grasset, 1923.

10 - McGraw, H. Ward, ed. Prose and Poelry of England. Chicago: The L. W. Singer Co., 1940.

11 - Otis and Needleman. Outlino-History of English Literafure, vol. II. New York: Barnes \& Noble, Inc. 1959.

12 - Scholes, Percy A. Oxford Companion to Music. Oxford University Press, 1970.

13 - Shelley, Percy B - Selections from Shelley's Poetry and Prose. Welland. Dennis, ed. London: Hutchinson Educational Ltda., 1961.

14 - Shelley, Percy B. Shelloy - Poetical Works. Hutchinson, Thomas, ed. Oxford University Press. 1970. 